\title{
Microbial trophodynamics in the Delaware Estuary
}

\author{
Richard B. Coffin*, Jonathan H. Sharp \\ College of Marine Studies, University of Delaware, Lewes, Delaware 19958, USA
}

\begin{abstract}
The relationship between bacteria, phytoplankton and heterotrophic microflagellates is examined over large spatial and seasonal scales in the Delaware Estuary, USA. The estuary was sampled along the main salinity axis (0 to $30 \mathrm{ppt}$ ), from near Philadelphia to the mouth, between February and August 1985. Samples were analysed for bacterial abundance and production, for heterotrophic microflagellate abundance and grazing rate on bacteria, and for phytoplankton production and biomass. Temperature was a major factor that regulated bacteria and microflagellates. With the exception of cold periods, bacteria and microflagellates appeared to respond to phytoplankton production. During the spring and summer, bacterial production and microflagellate grazing were highest in the lower estuary, where phytoplankton production was also highest. Bacterial production was on average $23 \%$ of the phytoplankton carbon production. In this area of the estuary grazing on bacteria was highest. Bacterivores grazed $95 \%$ of the bacterial production. Estimates on the carbon flow from phytoplankton to bacteria and subsequently to microflagellates suggest that bacteria and microflagellates do not return lost phytoplankton production to the main phytoplankton-zooplankton food chain in the Delaware Estuary. Instead, it appears that the primary effect of heterotrophic microbes is the mineralization of organic compounds to their inorganic constituents.
\end{abstract}

\section{INTRODUCTION}

An important problem in aquatic microbial ecology is the dynamics of the bacterial trophic level in relation to substrate sources and predators. Recent studies report that bacterial particulate carbon production ranges between 10 and $50 \%$ of phytoplankton production (Azam \& Fuhrman 1984). Such estimates indicate that a large portion of phytoplankton production may pass through the bacterial trophic level. Also, it has recently been observed that heterotrophic microflagellates are active bacterial grazers (Fenchel 1982a to d, Davis \& Sieburth 1984, Fuhrman \& McManus 1984, Wright \& Coffin $1984 a$, b). Although studies have addressed this problem, it is not clear whether bacteria, via microflagellate grazing, serve as a link between dissolved organic material (DOM) and higher trophic levels, or if DOM is used primarily to meet bacterial maintenance energy demands.

Several studies have suggested that heterotrophic microflagellates are able to consume a significant por-

\footnotetext{
- Present address: Technical Resources Inc., clo U. S. Environmental Protection Agency, Sabine Island, Gulf Breeze, Florida 32561, USA
}

tion of bacterial production (Fenchel 1982d, Fuhrman \& McManus 1984, Wright \& Coffin 1984b). Recently, it has been hypothesized that the link between bacterial and heterotrophic microflagellate trophic levels through grazing provides an important pathway by which organic matter lost from primary production may be returned to the traditional phytoplankton-zooplankton food chain (Williams 1981, Azam et al. 1983). However, the transfer of lost phytoplankton production back to the main food chain has not been documented. In fact, Ducklow et al. (1986) presented results that were contradictory to the hypothesis that the microbial loop resulted in a more efficient food chain. In a single experiment, these researchers measured the transfer of only $2 \%$ of radiolabeled glucose to higher trophic levels over a period of $13 \mathrm{~d}$ in a large-scale enclosure experiment. From this experiment, they concluded that bacteria are a sink for carbon.

In this study, we examine the relationship of phytoplankton, bacteria and heterotrophic microflagellates over large spatial and seasonal scales in the Delaware Estuary. Special consideration is given to the bacterial role in producing particulate carbon from lost primary production for subsequent consumption by heterotrophic microflagellates. We address the feasibility of 
bacteria acting as an intermediate between dissolved organic matter and higher trophic levels. Sampling over large temporal and spatial scales allows additional insight into the factors that influence estuarine food webs.

\section{STUDY AREA AND SAMPLE ACQUISITION}

The Delaware Estuary is a drowned river valley with a drainage basin of $33000 \mathrm{~km}^{2}$ that extends into the Pocono and Catskill Mountains (Fig. 1). In addition to nutrient inputs from the extensive drainage basin, municipal and industrial point sources around Philadelphia, Pennsylvania, result in very high inorganic nutrient concentrations at the head of the estuary (Sharp et al. 1982). However, dissolved organic and metal concentrations in the Delaware Estuary are not exceptionally high (Sharp et al. 1984, Church 1986). Another important characteristic of the Delaware Estuary is a prevalent turbidity maximum located between salinities of 2 and 10 ppt (Biggs et al. 1983). For most of the year, the estuary is vertically well mixed; however, increased river flow during spring runoff creates vertical stratification (Sharp et al. 1986). In the lower estuary, peaks in phytoplankton production during the

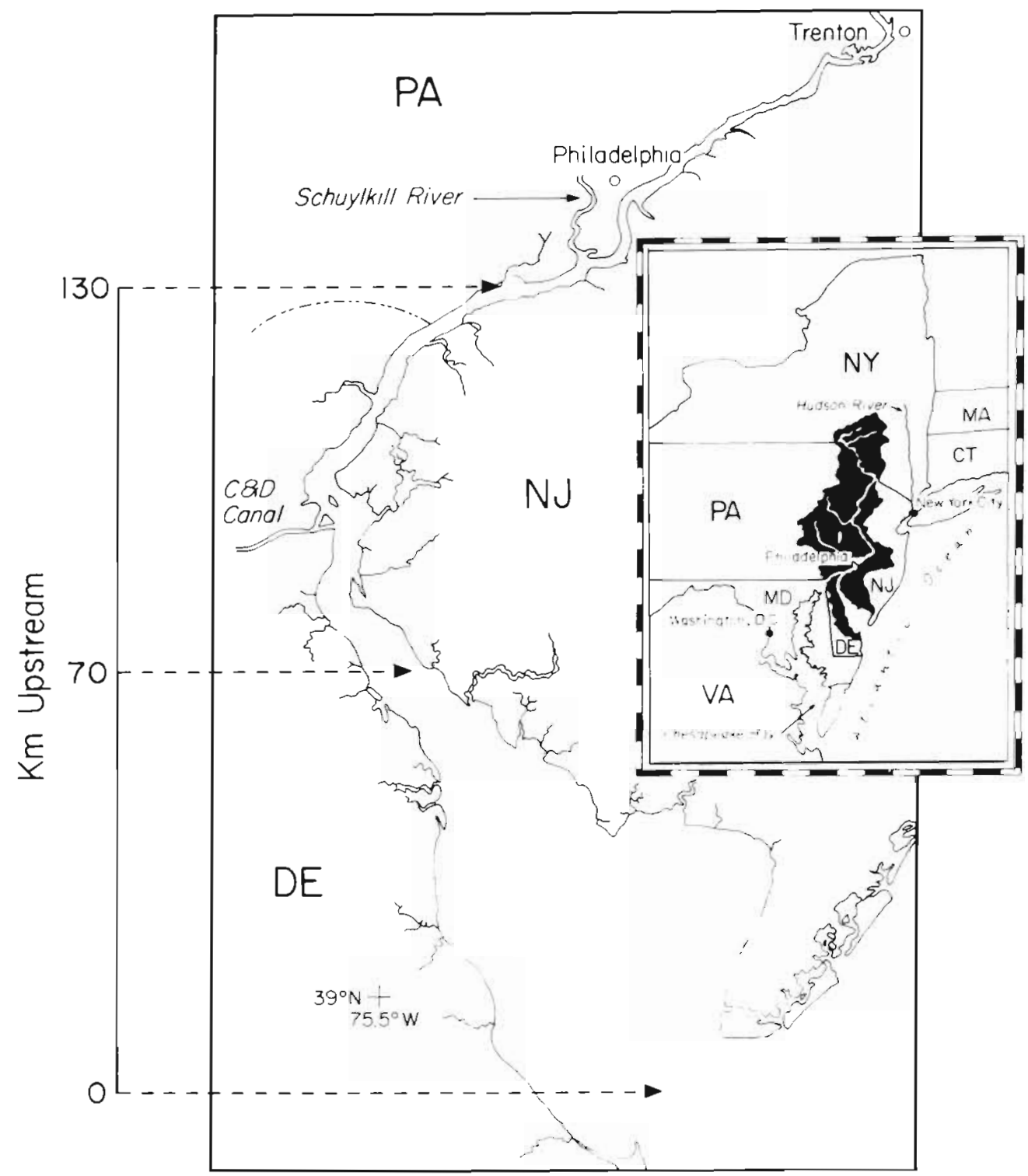

Fig. 1. The Delaware Estuary with distances from bay mouth shown in kilometers. Insert shows location along the east coast of the United States and drainage basin (dark) 
spring and summer are stimulated by increased light levels where suspended sediment concentrations are low and when stratification occurs, and by seasonal nutrient inputs (Pennock 1985, Pennock \& Sharp 1986).

The Delaware Estuary was sampled 18 times between September 1982 and October 1985 from the R/V Cape Henlopen. Generally, sampling covered each season during this period. From February to June 1985 we sampled every 2 to $3 \mathrm{wk}$ from the initiation to the dissipation of the spring phytoplankton bloom. Normally, 10 to 14 samples were taken along the main estuarine salinity axis, between salinities of 0 and 32 ppt. Regular stations along the main salinity axis were fixed geographic locations; however, extra samples were taken through sharp salinity gradients.

Water samples were taken $1 \mathrm{~m}$ below the water surface with 101 Niskin bottles. During sampling, conductivity, temperature, and depth were measured with a Neil-Brown Mark IIrb CTD system attached to a rosette sampler. Subsamples from the Niskin bottles were poured into acid-rinsed polycarbonate bottles and immediately prepared for analysis, as discussed below. Processing time was less than half an hour.

\section{METHODS}

Microscopic methods. Bacteria were counted using the acridine orange epifluorescence direct microscopic technique described by Hobbie et al. (1977). For each sample, enough complete fields were counted to accumulate at least 400 bacteria or 20 fields, whichever came first. Duplicates were determined not to be necessary, since replicate counts of identical samples varied by less than $5 \%$. Bacterial biomass was estimated by photographing random microscopic fields from the acridine orange preparations. Bacterial sizes were obtained from the photographs by calibration with fluorescent spheres ranging in size from 0.25 to $3.83 \mu \mathrm{m}$ and a $10 \mu \mathrm{m}$ stage micrometer. Average bacterial biovolumes were calculated with a minimum observation of 50 cells taking into consideration rodand sphere-shaped cells. We were careful to measure only the size of the bacterial cell wall and not the fluorescent halo around the bacteria. An estimate of the carbon content of the bacterial assemblage was made with a volume to carbon conversion factor. Bratbak (1985) suggested use of a factor of $5.6 \times 10^{-13}{\mathrm{~g} \mathrm{C} \mu \mathrm{m}^{-3}}^{-3}$ for samples that had been preserved with formalin. This value was used for our conversions.

Heterotrophic microflagellates were counted with the primulin epifluorescence method described by Caron (1983). Microflagellates were collected on $0.6 \mu \mathrm{m}$ Nuclepore filters under low vacuum pressure $(<100 \mathrm{~mm} \mathrm{Hg})$ and stained for $20 \mathrm{~min}$ with primulin.
Prepared slides were viewed with the acridine orange filter set. The yellow fluorescence of the primulin dye did not interfere with the red fluorescence of chlorophyll associated with phototrophic organisms; thus heterotrophic microflagellates could be differentiated from phototrophic microflagellates. Only cells without chlorophyll and with flagella were counted as heterotrophic microflagellates. These criteria do not include microflagellates that graze cyanobacteria and heterotrophic dinoflagellates, therefore these should be considered minimum grazing rates. Either 100 cells or 40 fields, which ever came first, were counted for each sample. Microflagellate biomass was estimated by assuming an average cell diameter of $3.0 \mu \mathrm{m}$ for calculations of cell volumes. A volume to carbon conversion

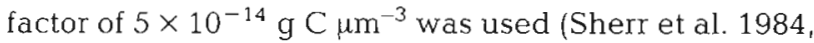
Wright et al. in press). An Olympus Vanox epifluorescent microscope was used for all microscopy.

Phytoplankton biomass was estimated from chlorophyll concentrations by assuming $30 \mu \mathrm{g} \mathrm{C}(\mu \mathrm{g} \mathrm{Chl} a)^{-1}$ (Strickland 1960, Parsons et al. 1984). A broad range of conversion factors have been reported in the literature; 30 is a generally accepted value for actively growing diatoms. This value was chosen because Skeletonema costatum was a dominant phytoplankter during this study (Pennock \& Sharp unpubl.).

Bacterial production and heterotrophic microflagellate grazing. Bacterial production and heterotrophic microflagellate grazing on bacteria were measured simultaneously with a modification of the method described by Wright \& Coffin (1984a). Two 11 water samples were placed in sterile Whirl-Pak bags, $10 \mathrm{mg}$ of cycloheximide was added to one bag, while the other was unamended. Cycloheximide, a eucaryotic ribosomal inhibitor, was used to inhibit grazing on bacteria by heterotrophic microflagellates (Fuhrman \& McManus 1984). This step was used in place of removing the grazing organisms with filtration as was described by Wright \& Coffin (1984a). The use of cycloheximide allows bacterial production to be measured in a turbid estuary without the filtration step causing a loss of bacteria attached to particles. Also this approach avoids filtration artifacts that could enhance the bacterial production rate. Bacterial production was measured as the slope of the linear portion of the line of bacterial density vs time from 5 to 7 subsamples of the sample containing cycloheximide over a $24 \mathrm{~h}$ period. The grazing rate on bacteria was calculated as the difference of the slopes of bacteria vs incubation time in the unamended sample and the sample containing cycloheximide. No exponential functions were used in these equations because a linear change of bacteria over time was normally observed in the samples. Similar results were reported by Wright \& Coffin (1984a) and Christian et al. (1982). Counts from initial or final 
subsamples were dropped if they did not conform to a linear growth function. To determine if grazing and production incubations were significantly different in each experiment, the slopes of the 2 lines were tested with the Student's t-test (1-tailed test, $\alpha=0.01$ ).

Phytoplankton production and routine analyses. Primary carbon production was measured with the ${ }^{14} \mathrm{C}$ bicarbonate uptake method described in Pennock \& Sharp (1986). Chlorophyll a was determined fluorometrically following the method of Strickland \& Parsons (1972) on a Turner model 111 fluorometer. Routine chemical analyses of water samples were run as described in Sharp et al. (1982).

\section{RESULTS AND DISCUSSION}

\section{Microbial abundance}

\section{Bacteria}

From the winter to the summer of 1985 , bacterial populations ranged between 1 and $8 \times 10^{9}$ cells $\mathrm{l}^{-1}$ (Fig. 2). Values were at the low end of ranges reported by researchers in other US east coast estuaries. These include 1.95 to $18.4 \times 10^{9} \mathrm{l}^{-1}$ in the Newport River Estuary, North Carolina (Palumbo \& Ferguson 1978), 0.7 to $15.0 \times 10^{9} \mathrm{l}^{-1}$ in northern Massachusetts saltmarsh estuaries (Wright \& Coffin 1983, Wright et al. in press), 0.3 to $53.9 \times 10^{9} \mathrm{l}^{-1}$ in the Rhode River Estuary, Maryland (Rublee et al. 1984), and approximately 2.0 to $25.0 \times 10^{9} \mathrm{l}^{-1}$ in the Chesapeake Bay (Malone et al. 1986).

Bacterial abundance showed a significant correlation with temperature; from our regression analysis, $r=$ $0.832(\mathrm{n}=198)$ for all data between September 1982 and August 1985. Other studies have reported that temperature is an important factor regulating bacterial numbers in estuaries (Vaatanen 1980, Wilson \& Stevenson 1980, Wright \& Coffin 1983). Temperature appeared to control bacterial activity in spite of the presence of high amino acid concentrations in areas where phytoplankton production was high during the winter (Coffin 1986). In fact, phytoplankton production rates were high in the estuary during February and March when bacterial abundance was the lowest. Similar results were recently reported by Pomeroy \& Deibel (1986) during a phytoplankton bloom in Newfoundland coastal waters. They estimated that bacteria required 9 times longer to utilize particulate material at $-0.2{ }^{\circ} \mathrm{C}$ than at 20 to $25^{\circ} \mathrm{C}$.

Although temperature was an important factor regulating bacterial abundance on a seasonal basis, other factors were also important during the spring, summer and fall. Bacterial numbers did not vary greatly along the salinity gradient, with the exception of peaks in the lower bay. This pattern indicates that a source of bacterial substrate existed in the lower estuary (Fig. 2). High phytoplankton production in the lower Delaware Estuary (Pennock \& Sharp 1986) could be a source of organic matter for bacteria. Dissolved amino acid concentrations were high in the lower estuary for the February and August 1985 sampling period (Coffin 1986). Also, maxima of bacterial densities and phytoplankton production occurred in the lower estuary. For the full period of September 1982 to August 1985, bacterial densities correlated significantly with phytoplankton production $(\mathrm{r}=0.340, \mathrm{n}=187)$, while the correlation of bacteria with phytoplankton biomass (chlorophyll) was not significant $(\mathrm{r}=-0.054, \mathrm{n}=190)$.

Reports from some other estuaries have indicated that bacterial numbers are highest in the upper estuary (Palumbo \& Ferguson 1978, Albright 1983) and in the mid-estuary (Wright \& Coffin 1983). The pattern of bacterial abundance in an estuary is a result of the bacterial substrate sources in that specific estuary. The supply of substrate is a function of physical, chemical and morphological parameters characteristic of each

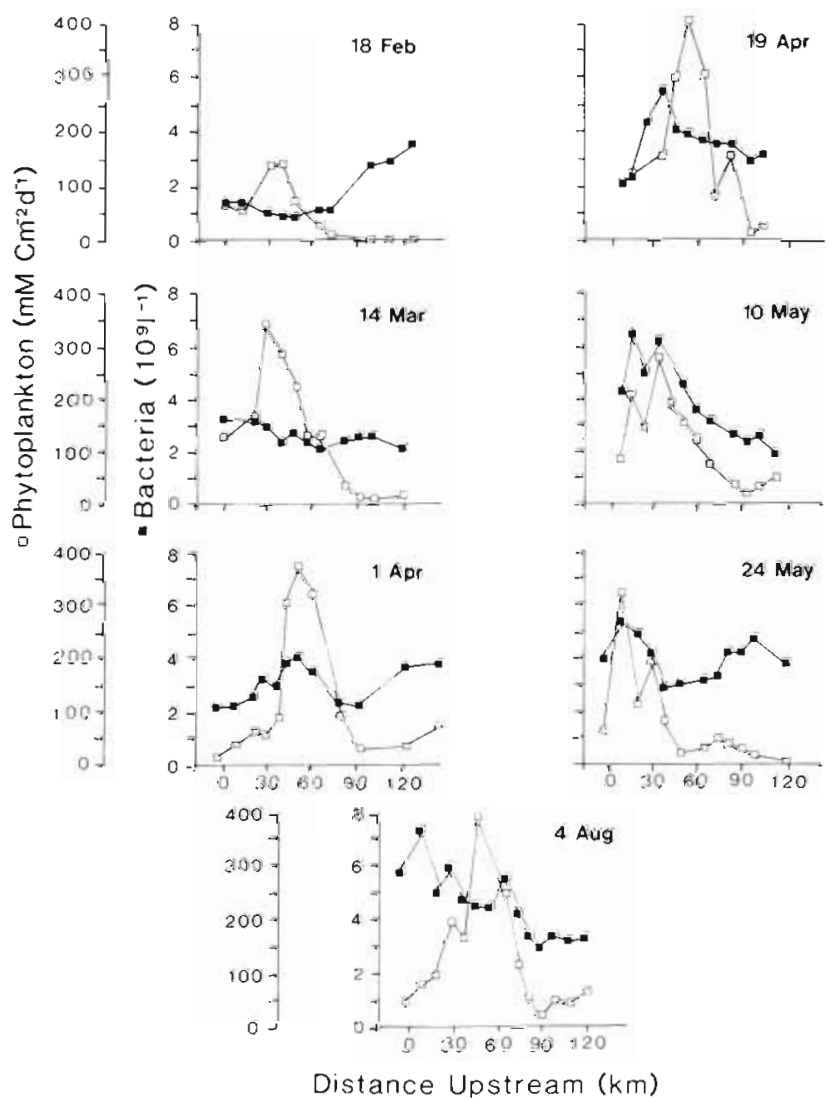

Fig. 2. Bacterial abundance and phytoplankton production from transects between February and August 1985 
estuary. For example, Albright (1983) reported that highest bacterial numbers in the upper estuary of several British Columbia rivers resulted from riverine input. In a salt marsh estuary, Wright \& Coffin (1983) suggested that highest bacterial numbers were commonly observed in the middle of the estuary as a result of tidal flushing of the surrounding salt marsh. Spring stratification, greater light and high turbidity in the lower Delaware result in higher phytoplankton production (Sharp et al. 1986). This production appears to provide more substrate to bacteria in the Delaware Estuary than the river and salt marshes, resulting in maximum bacterial densities in the lower estuary.

Bacterial volumes varied from 0.019 to $0.142 \mathrm{\mu m}^{3}$ with distinct spatial and seasonal patterns (Fig. 3). Mean cell volumes from the February and August 1985 samplings were respectively larger and smaller than mean volumes during the other samplings (Student's t-test, $\alpha=0.05$ ). Also, the mean cell volume at all stations of salinities lower than 10 ppt was significantly larger $(\alpha=0.05)$ than that at down-river stations. Simon (1987) reported that cell volumes ranged from 0.028 to $0.104 \mu^{3}$ in Lake Constance, Germany. In that study, largest volumes coincided with highest bacterial production during the spring phytoplankton bloom. In the Delaware Estuary, bacteria were smallest when bacterial production and grazing rates were greatest, suggesting that grazing pressure resulted in smaller bacterial sizes. These results are supported by the study of Andersson et al. (1986), who observed an inverse relation of bacterial volumes and microflagellate abundance in the Baltic Sea. In fact, chemostat studies revealed selection of larger bacteria by the phagotrophic microflagellate Ochromonas sp. (Andersson et al. 1986).

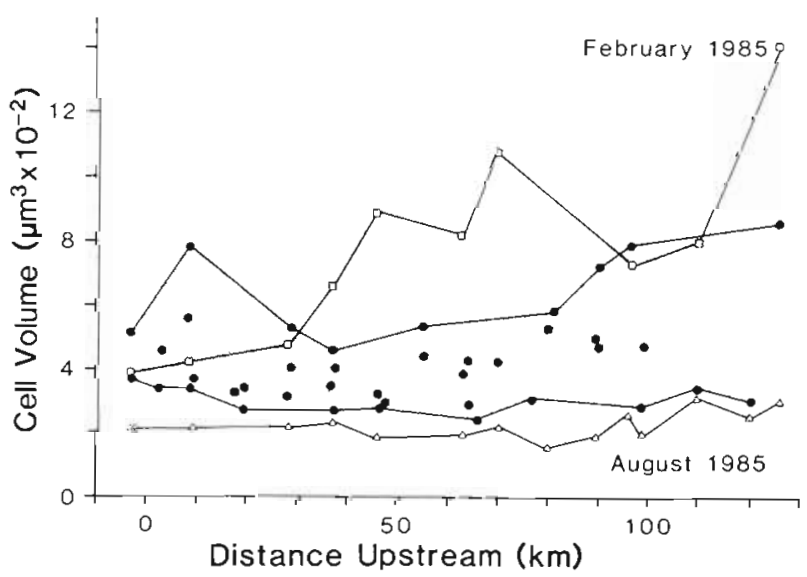

Fig. 3. Bacterial cell volumes for samplings between February and August 1985. Separate plots are shown for February and August with an envelope of values for the 5 intervening samplings

\section{Heterotrophic microflagellates}

Heterotrophic microflagellates ranged from a winter minimum of $0.4 \times 10^{6}$ cells $]^{-1}$ to a summer maximum of $9 \times 10^{6}$ cells $^{-1}$ (Fig. 4). Microflagellate abundance, like that of bacteria, correlated significantly with temperature $(\mathrm{r}=0.51, \mathrm{n}=82$ ). In the late May sampling a large drop in the microflagellate population corresponded to decreases in phytoplankton and bacterial biomass and production. Microflagellate numbers were considerably more variable spatially and seasonally than bacterial numbers. Fenchel (1986) also reported microflagellate populations being more variable than bacterial populations in the Limfjord, Denmark. He hypothesized that the ratio of the maximum to minimum microflagellate populations is directly proportional to the environmental carrying capacity for bacteria. For bacteria in seawater, the carrying capacity is the equilibrium population in the absence of grazing pressure. A major factor that influences the carrying capacity is the amount of substrate available to bacteria. Thus, this hypothesis suggests that the greater the variation in microflagellate densities, the higher the bacterial carrying capacity. In the Delaware

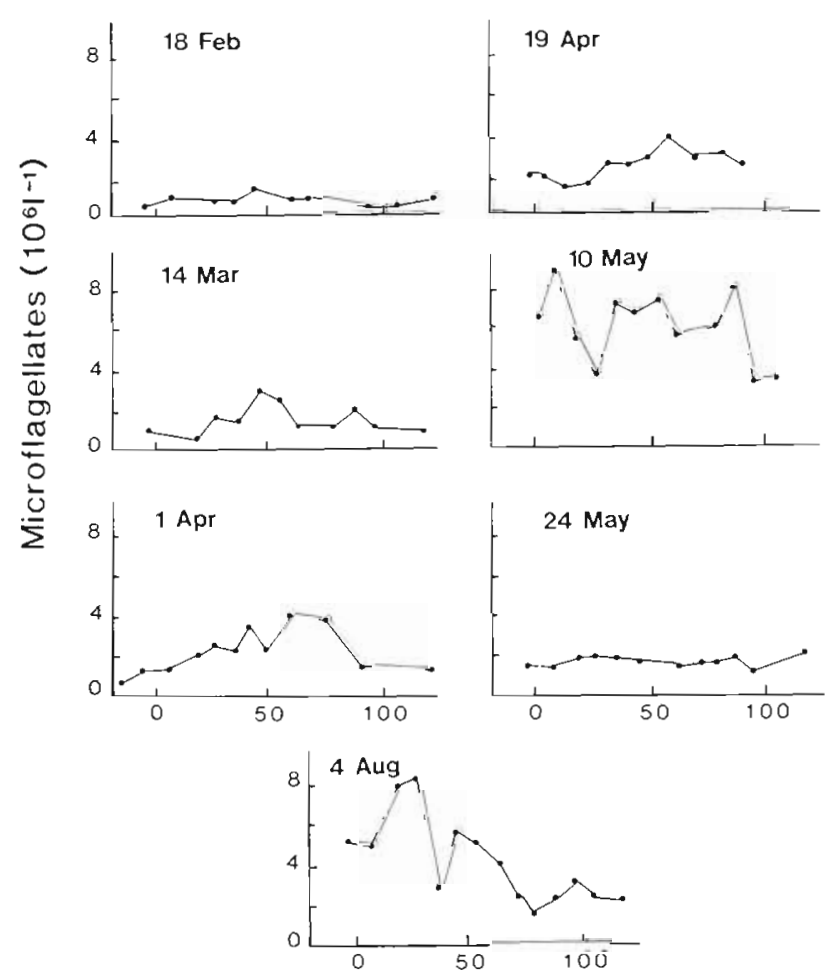

Distance Upstream ( $\mathrm{km})$

Fig. 4. Heterotrophic microflagellate abundances from salinity transects between February and August 1985 
Estuary, an important factor that influenced the bacterial carrying capacity appeared to be dissolved organic matter from phytoplankton. With the high temporal and spatial variation in phytoplankton production and dissolved amino acids (Coffin 1986), one expects a large variation in the bacterial carrying capacity.

Heterotrophic microflagellate numbers in the Delaware Estuary compared well with values reported for other systems; abundances range from 1 to $10 \times 10^{6}$ cells $\mathrm{I}^{-1}$ for coastal and estuarine environments (Fenchel 1982d, Sherr \& Sherr 1983, Davis \& Sieburth 1984, Wright \& Coffin in press). Highest microflagellate densities were generally observed near regions of high phytoplankton and bacterial production; exact correspondence of maxima was not always observed. Wright $\&$ Coffin (in press) observed a similar spatial relationship in which microflagellate abundances were lower in the center of the Parker River estuary (northern Massachusetts), even though bacterial activity was generally higher in this part of the estuary. Further observation has suggested that ciliate abundances are frequently highest in this area of the Parker River estuary (Coffin \& Wright unpubl.). In the Delaware

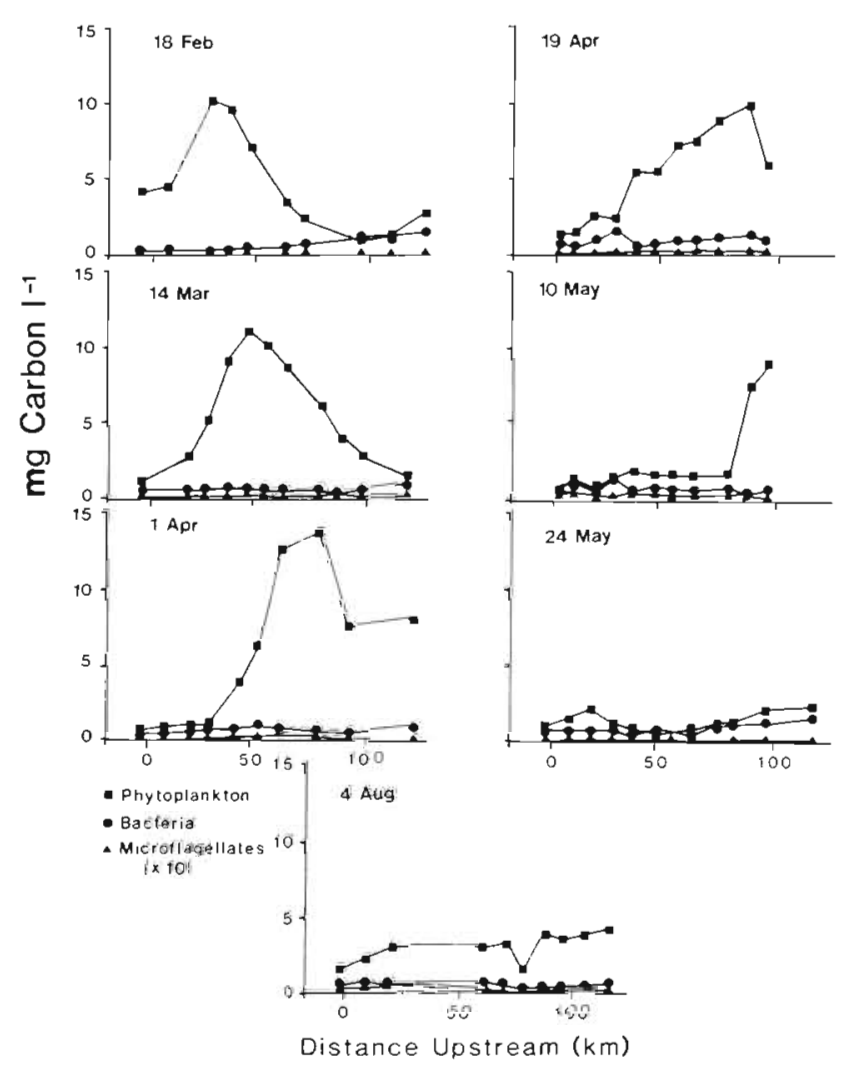

Fig. 5. Standing biomass in carbon of bacteria, phytoplankton and heterotrophic microflagellates from transects between February and August 1985
Estuary, the lowered microflagellate numbers may be a result of grazing by ciliates. Additionally, ciliates may be responsible for a substantial percentage of bacterial grazing (Sherr et al. 1986a, Sherr et al. 1987).

\section{Microbial biomass}

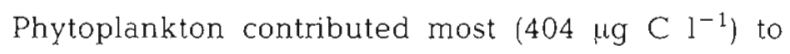
microbial carbon standing stocks from February to August (Fig. 5). Over the entire sampling period, the bacterial contribution averaged $75 \mu \mathrm{g} \mathrm{C} \mathrm{l}^{-1}$ or $19 \%$ of the phytoplankton biomass. However, in the upper river and after the spring phytoplankton bloom, the bacterial biomass was frequently equivalent to that of phytoplankton. The heterotrophic microflagellate biomass was always low in comparison to phytoplankton and bacteria, with an average of only $2 \mu \mathrm{g} \mathrm{C} \mathrm{l}^{-1}$.

\section{Bacterial production and grazing on bacteria}

Bacterial production rates were more variable than bacterial abundances from February to August 1985. Production ranged from nearly 0 to $152 \mu \mathrm{g} \mathrm{C} \mathrm{l}^{-1} \mathrm{~d}^{-1}$. Spatial and seasonal trends (Fig, 6) suggest that bacterial production rates were influenced by several factors. In the winter, temperature regulated bacterial production $(r=0.62, n=41)$, as it did bacterial abundance. However, comparison of carbon production (Table 1) with bacterial cell production indicated that the influence of temperature was not as great on carbon production. Average bacterial cell production rates compared between the February and August samplings were 0.24 and $3.37 \times 10^{9}$ bacteria $\mathrm{l}^{-1} \mathrm{~d}^{-1}$, respectively; a range of 14 -fold. Average bacterial carbon production from the same samplings ranged from 9.53 to $44.9 \mu \mathrm{g} \mathrm{C} \mathrm{l}^{-1} \mathrm{~d}^{-1}$, a range of only 5 -fold. The larger bacterial volumes during the winter cruise yielded a higher bacterial carbon production than that which was observed with abundances alone. From early April through the remainder of the spring, bacterial production stayed high in the lower estuary, and to a lesser extent, in the upper estuary where phytoplankton production was high. Spatial orientation of bacterial and phytoplankton production suggests that phytoplankton were an important bacterial substrate source; however, the correlation between bacterial and phytoplankton production was not significant $(r=0.046$, $n=41$ ). This observation is discussed in more detail below.

With the exception of one high value, bacterial production in the Delaware Estuary was similar to measurements in other estuaries in which phytoplankton production is the primary nutrient source. Table 2 presents 


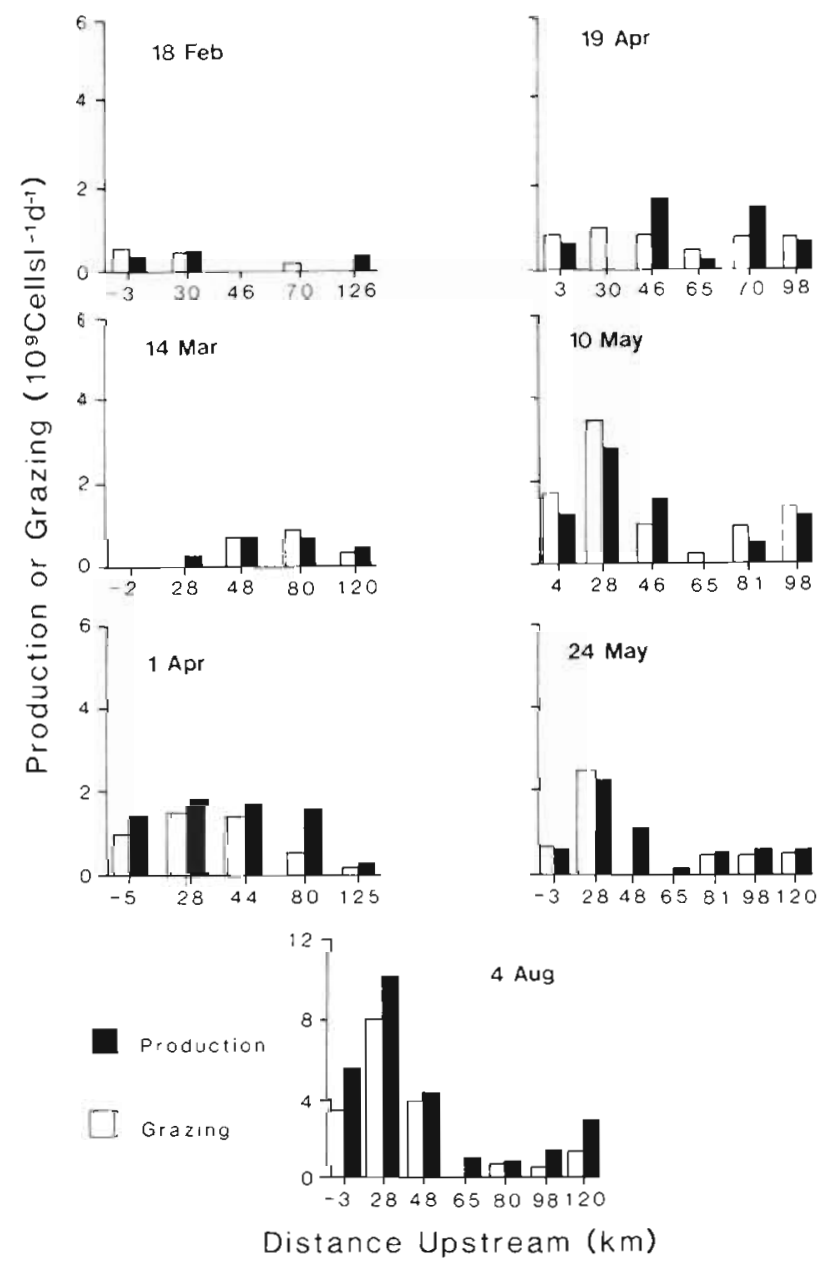

Fig. 6. Bacterial production and grazing on bacteria by heterotrophic microflagellates for stations along salinity transects from February to August, 1985

bacterial production measurements from different systems for comparison with the value for the Delaware. Production is high in eutrophic lakes, where municipal inputs and macrophytes are important nutrient sources (as high as $170 \mu \mathrm{g} \mathrm{C} \mathrm{l}^{-1} \mathrm{~d}^{-1}$; Bell et al. 1983) and salt marshes (as high as $409 \mu \mathrm{g} \mathrm{C} \mathrm{l}^{-1} \mathrm{~d}^{-1}$; Wright \& Coffin 1984 a). Low production occurs in oligotrophic systems such as the Sargasso Sea (8.0 $\mathrm{g} \mathrm{Cl}^{-1}$; Cuhel et al. 1983),

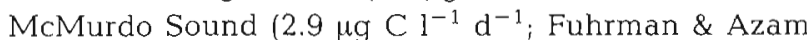
1980) and the Irish Sea $\left(12.7 \mu \mathrm{g} \mathrm{C} \mathrm{l}^{-1} \mathrm{~d}^{-1}\right.$; Turley \& Lochte 1985). The values from the Delaware Estuary compare well to the Chesapeake Bay (Malone et al. 1986) and the York River, Virginia (Ducklow 1982), other systems in which bacteria respond strongly to phytoplankton production.

Our production estimates depend upon the inhibition of bacterial grazers with cycloheximide. Recently the effectiveness of cycloheximide as an inhibitor of bac- terivores has been examined (Sanders \& Porter 1986 Sherr et al. 1986b, Taylor \& Pace 1987). Results from these studies indicate that ciliate grazing on bacteria is not entirely inhibited by cycloheximide. However, the results from those studies were not consistent and the effect of cycloheximide may vary between species. Ciliates have been reported to be capable of grazing a high percentage of bacterial production (Sherr and Sherr 1987). In waters where ciliates are important grazers on bacteria, the use of only cycloheximide could underestimate bacterial production. Wright (unpubl.) has compared bacterial production using cycloheximide to inhibit and $1.0 \mu \mathrm{m}$ Nuclepore filters to remove grazers. From 6 comparisons no distinct trend was observed; rates were relatively similar. In those samples, ciliates may not have been active grazers of bacteria or the ciliate species present may have been sensitive to the cycloheximide. Production estimates from our study compare well with other values measured with tritiated thymidine and frequency of dividing cells from other systems; these methods do not depend on inhibition of bacterivores. Further, recent measurements of bacterial production in the Delaware Estuary with tritiated thymidine are compatible with the estimates reported in this study (Kirchman pers. comm.). Considering the relatively high bacterial production rates in the Delaware Estuary, we believe that either the grazing of ciliates was largely inhibited or ciliates were not active bacterial grazers in our samples.

Another artifact associated with the use of antibiotics to inhibit bacterivores may be an uncoupling of bacteria from a nitrogen source. Sherr et al. (1986b) suggested that inhibition of protozoans could stop regeneration of nitrogen that is important to bacterial growth. This could also underestimate bacterial production measurements. In our study, relatively high and low bacterial production measurements were observed during the late spring and early summer at adjacent stations in the lower estuary. After the spring bloom, $\mathrm{NH}_{4}^{+}$concentrations are characteristically consistent and low (around 1 to $2 \mu \mathrm{M}$ ) in the lower Delaware Estuary (Sharp et al. 1982). Thus, low bacterial production is most likely a result of the effect of substrate supply and grazing on bacteria (discussed in detail below), rather than a methodological artifact.

Cycloheximide has also been reported to inhibit bacteria (Taylor \& Pace 1987). In that study, cycloheximide concentrations were $50 \mathrm{mg}^{-1}$. Lower concentrations, e.g. $5 \mathrm{mg} \mathrm{l}^{-1}$, do not appear to have a significant influence on bacterial production and still inhibit bacterial grazers (Lebo \& Wright unpubl.). Therefore, with the lower cycloheximide concentrations used in this study, we do not believe estimates of bacterial production were lowered by the cycloheximide. 
Table 1 Bacterial production (B) and microflagellate grazing (G) on bacteria from February to August 1985 expressed as cell production (cells $\times 10^{9} \mathrm{l}^{-1} \mathrm{~d}^{-1}$ ) and carbon production $\left(\mu \mathrm{g} \mathrm{C} \mathrm{l^{-1 }} \mathrm{d}^{-1}\right.$ )

\begin{tabular}{|c|c|c|c|c|c|c|c|c|}
\hline \multirow[t]{2}{*}{ Stn } & \multicolumn{2}{|c|}{ Cell } & \multicolumn{2}{|c|}{ Carbon } & \multicolumn{2}{|c|}{ Cell } & \multicolumn{2}{|c|}{ Carbon } \\
\hline & $B$ & G & $B$ & $\mathrm{G}$ & $B$ & $\mathrm{G}$ & B & $G$ \\
\hline & \multicolumn{2}{|c|}{18 Feb 1985} & \multicolumn{6}{|c|}{14 Mar 1985} \\
\hline $\mathrm{CH}$ & 0.35 & $0.55^{\circ}$ & 7.57 & 11.89 & 0 & 0 & 0 & 0 \\
\hline S25 & 0.52 & $0.51^{\circ}$ & 13.8 & 13,86 & 0.24 & 0 & 4.57 & 0 \\
\hline$\$ 20$ & 0 & 0 & 0 & 0 & 0.69 & $0.70^{\circ}$ & 17.54 & 17.8 \\
\hline S15 & - & - & - & - & - & - & - & - \\
\hline $\mathrm{S} 10$ & 0 & 0.16 & 0 & 9.68 & 0.64 & $0.88^{\circ}$ & 15.2 & 20.9 \\
\hline S5 & - & - & - & - & - & - & - & - \\
\hline \multirow[t]{2}{*}{ So } & 0.33 & 0 & 26.24 & 0 & 0.48 & 0.32 & 23.1 & 15.41 \\
\hline & \multicolumn{2}{|c|}{19 Apr 1985} & \multicolumn{6}{|c|}{10 May 1985} \\
\hline $\mathrm{CH}$ & 0.56 & 0.72 & 24.77 & 31.85 & 1.1 & $1.60^{\circ}$ & 31.17 & 45.34 \\
\hline$\$ 25$ & 0 & 0.86 & 0 & 25.72 & 2.67 & $3.34^{*}$ & 65.49 & 81.92 \\
\hline $\mathrm{S} 20$ & 1.62 & 0.75 & 26.31 & 12.18 & 1.47 & $0.85^{\circ}$ & 33.26 & 19.23 \\
\hline S15 & 0.15 & 0.42 & 3.6 & 10.07 & 0 & 0.13 & 0 & 2.40 \\
\hline$\$ 10$ & 1.48 & $0.72^{\circ}$ & 43.6 & 21.21 & 0.48 & $0.77^{\circ}$ & 14.95 & 23.98 \\
\hline S5 & 0.65 & $0.76^{\circ}$ & 17.18 & 20.09 & 1.12 & $1.32^{\circ}$ & 28.06 & 3.71 \\
\hline \multirow[t]{2}{*}{ So } & - & - & - & - & - & - & - & - \\
\hline & \multicolumn{2}{|c|}{24 May 1985} & \multicolumn{6}{|c|}{4 Aug 1985} \\
\hline $\mathrm{CH}$ & 0.44 & 0.54 & 9.02 & 11.07 & 3.26 & $3.62^{\circ}$ & 28.84 & 32.03 \\
\hline $\mathrm{S} 25$ & 2.2 & $2.46^{\circ}$ & 41.89 & 46.84 & 10.5 & $8.50^{\circ}$ & 151.7 & 122.8 \\
\hline S20 & 1.05 & 0 & 31.28 & 0 & 4.22 & $3.96^{\circ}$ & 49.63 & 46.57 \\
\hline S15 & 0.11 & 0 & 1.76 & 0 & 0.86 & 0.08 & 11.27 & 1.05 \\
\hline $\mathrm{S} 10$ & 0.51 & 0.48 & 13.48 & 12.69 & 0.65 & 0.62 & 7.06 & 6.74 \\
\hline S5 & 0.68 & 0.53 & 19.50 & 15.5 & 1.31 & 0.30 & 18.78 & 4.2 \\
\hline So & 0.56 & 0.53 & 24.40 & 23.09 & 2.81 & 1.19 & 46.89 & 19.86 \\
\hline
\end{tabular}

Table 2. Comparison of bacterial production measurements with this study. tdr: production measurements using the tritiated thymidine technique; fdc: production measurements with the frequency of dividing cells method; adn: tritiated adenine method; $S^{35}$ : sulfur incorporation method; inc: studies in which bacterial production was measured with observation of abundance over time

\begin{tabular}{|c|c|c|c|}
\hline $\begin{array}{l}\text { Production rate } \\
\left(\mu \mathrm{g} \mathrm{C} \mathrm{l}^{-1} \mathrm{~d}^{-1}\right)\end{array}$ & Site & Method & Source \\
\hline $0.0-2.9$ & McMurdo Sound, Antarctica & $\operatorname{tdr}$ & Fuhrman \& Azam 1980 \\
\hline $0.7-71.0$ & Scripps Pier, California/Saanich Inlet, British Columbia & $\operatorname{tdr}$ & Fuhrman \& Azam 1980 \\
\hline $4.8-170.0$ & Eutrophic Swedish lake & $\operatorname{tdr}$ & Bell et al. 1983 \\
\hline $7.0-75.0$ & York River, Virginia & $\operatorname{tdr}$ & Ducklow $1982^{a}$ \\
\hline $12.0-72.0$ & Chesapeake Bay, Maryland & $\operatorname{tdr}$ & Ducklow 1985 \\
\hline $1.6-2.4$ & Hudson River plume, New York & $\mathrm{tdr}$ & Ducklow \& Kirchman $1983^{\text {a }}$ b \\
\hline $10.7-71.9$ & Little Crooked Lake, Indiana & $\operatorname{tdr}$ & Lovell \& Konopka 1985 \\
\hline $0.1-29.3$ & Southern North Sea & $\operatorname{tdr}$ & Lancelot \& Billen 1984a, b \\
\hline $3.7-11.0$ & Caribbean Sea & $\operatorname{adn}$ & Karl 1979 \\
\hline 2.5 & Coastal Baltic Sea & $\mathrm{fdc}$ & Hagström et al. 1979 \\
\hline $0.0-60.0$ & Baltic Sea & $f d c$ & Larsson \& Hagström 1982 \\
\hline $19.2-178.0$ & Nearshore Georgia Bight & $\mathrm{fdc}$ & Newell \& Christian 1981 \\
\hline $8.0-46.0$ & NW Atlantic Ocean & $S^{35}$ & Cuhel et al. 1983 \\
\hline $4.8-34.0$ & Scripps Pier/Saanich Inlet & inc & Fuhrman \& Azam 1980 \\
\hline 12.7 & Irish Sea & inc & Turley \& Lochte 1985 \\
\hline $4.0-409.0$ & Parker River, Massachusetts & inc & Wright \& Coffin 1984 \\
\hline $0.0-151.7$ & Delaware Estuary, Delaware & inc & This study \\
\hline
\end{tabular}


Fig. 6 indicates that rates of microflagellate grazing on bacteria were tightly coupled with bacterial production rates $(\mathrm{r}=0.87, \mathrm{n}=41$ ). However, grazing did not correlate as well with bacterial abundance $(r=0.45$, $\mathrm{n}=41$ ). Flagellate grazing rates were frequently equivalent to bacterial production rates. These results, as well as results from other studies (Newell \& Linley 1984, Sherr et al. 1984, Wright \& Coffin 1984a) indicate that microflagellates are capable of consuming nearly all of the bacterial production. An observation that has bearing on the role of microbial transfer of DOM to higher trophic levels was the low heterotrophic microflagellate biomass relative to bacterial and phytoplankton biomass. Similar results have been observed by Wright et al. (in press). Considering the high grazing rates, the low microflagellate biomass suggests that either natural microflagellate populations are inefficient in building biomass from bacteria or that the microflagellate population turnover is very rapid. This observation needs further examination before the role of these microorganisms in the marine food chain can be understood.

\section{Phytoplankton as bacterial substrate}

The results of the present study suggest that phytoplankton are important producers of bacterial substrate in the Delaware Estuary. There was a large spatial variation in the ratio of phytoplankton to bacterial production rates. At some stations bacterial production was greater than $100 \%$ of phytoplankton production, suggesting that substrate sources other than immediate phytoplankton production may have been important. In the upper estuary, where large organic inputs may come from municipal and riverine sources, bacterial production was, occasionally, much greater than phytoplankton production. In the lower estuary bacterial production was between 0 and $357 \%$ of primary production. These estimates assume an instantaneous relationship between bacterial and phytoplankton production, and may not accurately describe bacterial uptake of phytoplankton carbon over longer time periods. This is probably the reason that phytoplankton and bacterial production did not always correlate.

Phytoplankton do not release large amounts of organic matter for bacterial consumption when they are in log phase (Sharp 1984). Our estimates for the Delaware Estuary suggest direct organic loss by phytoplankton of less than $10 \%$ of the fixed carbon (Murphy \& Sharp unpubl.). As a result of a possible time delay between phytoplankton and bacterial production, it is most descriptive to make comparisons on large spatial scale averages. Comparisons of areal phytoplankton production with bacterial production were made by converting bacterial cell production to total carbon uptake, assuming a $50 \%$ efficiency by the bacteria for building biomass, and integrating production over an average $7 \mathrm{~m}$ deep water column (Table 3). Table 3

Table 3. Percent bacterial production of primary carbon production calculated from averaged phytoplankton and bacterial production between estuarine mouth and $75 \mathrm{~km}$ upstream. Estimates of bacterial production are based on $50 \%$ assimilation of dissolved organic carbon by bacteria and an average $7 \mathrm{~m}$ deep estuarine water column

\begin{tabular}{|c|c|c|c|c|c|c|c|}
\hline & $\begin{array}{c}18 \\
\text { Feb }\end{array}$ & $\begin{array}{l}14 \\
\text { Mar }\end{array}$ & $\begin{array}{c}1 \\
\text { Apr }\end{array}$ & $\begin{array}{c}19 \\
\text { Apr }\end{array}$ & $\begin{array}{c}10 \\
\text { May }\end{array}$ & $\begin{array}{c}24 \\
\text { May }\end{array}$ & $\begin{array}{c}4 \\
\text { Aug }\end{array}$ \\
\hline $\begin{array}{l}\text { Bacterial } \\
\text { production } \\
\left(\mathrm{mMC} \mathrm{m}^{-2} \mathrm{~d}^{-1}\right)\end{array}$ & 6 & 11 & 49 & 23 & 34 & 23 & 58 \\
\hline $\begin{array}{l}\text { Phytoplankton } \\
\text { production } \\
\text { (mM C m }{ }^{-2} \mathrm{~d}^{-1} \text { ) }\end{array}$ & 70 & 177 & 111 & 209 & 123 & 74 & 182 \\
\hline $\begin{array}{l}\text { \% Uptake by } \\
\text { bacteria }\end{array}$ & 9 & 6 & 44 & 11 & 27 & 31 & 32 \\
\hline
\end{tabular}

presents averages of bacterial and phytoplankton production for stations between the mouth of the estuary and $75 \mathrm{~km}$ upstream. These stations represent the area of greatest phytoplankton production in the estuary; above $75 \mathrm{~km}$, türbidity frequently inhibits phytoplankton production through light limitation (Pennock 1985). The ratios of bacterial production to primary production varied between 6 and $44 \%$. An average of $23 \%$ of the primary production would appear to be required by bacteria for the period of February to August 1985; this is a substantial portion of the phytoplankton carbon. It is interesting to note that our estimates of direct phytoplankton excretion during the spring and summer period give a range of 0.2 to $27 \%$ of the production with an average of $6.9 \%$ (Murphy \& Sharp unpubl.). Either these are underestimates of organic excretion (as discussed in Murphy \& Sharp) or much of the bacterial carbon demand is coming from other carbon sources such as decay of dead phytoplankton cells (see Sharp 1984) or zooplankton influences (grazing losses, zooplankton excretion).

\section{Control of bacteria}

Recent investigations have concentrated on the factors that control bacterial abundances and production in aquatic systems (Kirchman et al. 1982, Wright \& Coffin 1984a, b, Ducklow \& Hill 1985, Wright in press, Wright et al. in press). The general consensus from these investigations is that bacterial abundance and production rate is a balance between substrate supply to bacteria and grazing on bacteria by heterotrophic 
microflagellates. Bacterial dynamic interactions with these parameters have been predicted with a logistic growth model (Wright \& Coffin 1984b). This model predicts that, in the absence of predators, bacterial growth is a function of the substrate supply. Thus, bacteria will achieve a maximum population that is characteristic of the substrate concentration. As a result of this unimpeded growth, production will be low and most of the substrate consumed by bacteria will be used for maintenance energy (Wright in press). With microflagellates present, the control of bacterial populations shifts to grazing pressure. With high grazing rates, bacterial production approaches the maximum growth rate for the population and bacterial populations are lower, below the carrying capacity. In this situation, less energy is used for cellular maintenance and more energy is transferred to bacterial grazers.

Individual incubation experiments were examined to observe the influence of predation and substrate on bacterial populations in the Delaware Estuary. Fig. 7 presents plots of incubation experiments that exhibit examples of substrate and grazing control on bacterial populations. Each plot contains 2 lines representing the change of bacterial numbers over the course of the incubation experiment. One line represents the sample that contained cycloheximide (antibiotic used to inhibit grazing) and the other represents growth in the

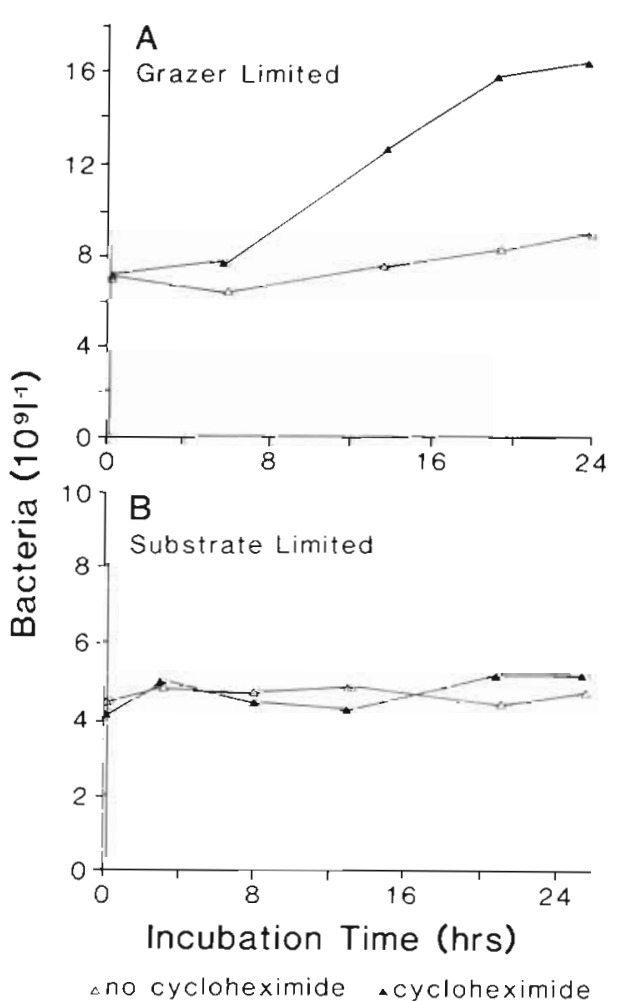

Fig. 7. Examples of incubation experiments displaying (A) grazer-limited, and (B) substrate-limited bacterial populations unamended sample. A grazing-limited system was typified by growth in the sample with cycloheximide (grazing was inhibited) and no growth or a decreased in bacterial abundance in the sample without cycloheximide present (Fig. 7A). On the other hand, a substratelimited system was characterized by little or no growth in either sample; lines representing the growth of the 2 samples were similar, and grazing rate was low (Fig. 7B).

A qualitative survey of the factors that influenced bacterial production in the estuary was conducted. Two bacterial growth conditions were observed. The conditions for these categories were arbitrary, established through observation of seasonal changes in production and grazing rates. One situation, grazing limited, was characterized by bacterial production rates greater than $1 \times 10^{9}$ cells $1^{-1} \mathrm{~d}^{-1}$ and a grazing rate of at least $25 \%$ of the bacterial production rate. The other case, substrate limited, had production rates of less than $1 \times 10^{9}$ cells $\mathrm{l}^{-1} \mathrm{~d}^{-1}$. Low bacterial activity associated with cold temperatures was also noted; this is not included as one of these conditions. Using these criteria, we found that substrate limitation occurred primarily in the upper estuary, while grazing control was observed to be important in the lower estuary (Fig. 8).

The influence of substrate and grazing on bacterial production in the Delaware Estuary was evident in the incubation experiments used to measure bacterial production rates. The qualitative survey of bacterial production revealed that bacteria were present in 2 distinct phases of logistic growth. In the upper estuary, bacteria were predominantly controlled by substrate concentration. This resulted in bacterial populations with Iow production rates. Hypothetically, available substrate was used for cellular maintenance, and bacteria were frequently a sink for energy in the upper estuary (Wright \& Coffin 1984b, Wright et al. in press). In the lower estuary, primary production appeared to provide substrate for bacteria in excess of their cellular maintenance requirement. In response to higher substrate supply, bacterial production was greater and allowed a population of bacterial grazers to develop. Grazing on bacteria prohibited a large increase in the bacterial abundance despite the increased substrate availability. In this case, bacteria were a link of energy to the next higher trophic level.

\section{The microbial loop}

In summary, using data from this study, we present a simple box model of the carbon flow from phytoplankton, to the bacterial and subsequently, microflagellate trophic levels. The purpose of this presentation is to 
Fig. 8. Qualitative evaluation of bacterial populations as either grazer-limited or substrate-limited. See text for criteria for each category. Observations for all 7 samplings are combined for this presentation

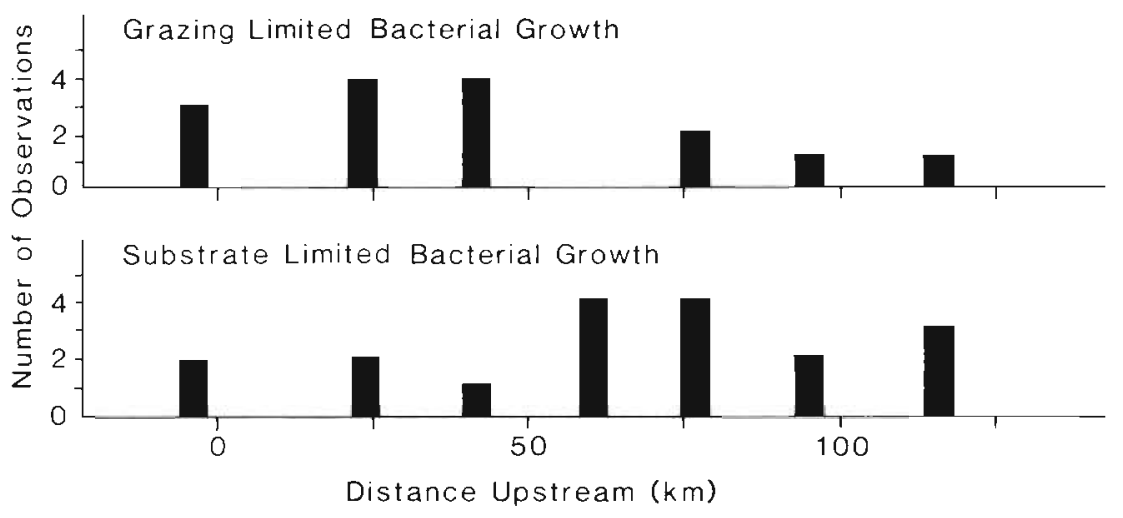

estimate the importance of the microbial loop in the Delaware Estuary. This is approached with an examination of the lower 2 trophic levels in the loop. Average phytoplankton production between the mouth of the Delaware Estuary and $75 \mathrm{~km}$ upstream, from February to August 1985, was $135 \mathrm{mM} \mathrm{C} \mathrm{m}^{-2} \mathrm{~d}^{-1}$ (Fig. 9). Average bacterial production for the same space and time scale was $14.5 \mathrm{mM} \mathrm{C} \mathrm{m}^{-2} \mathrm{~d}^{-1}$ or $11.5 \%$ pf the primary production. Assuming a bacterial assimilation efficiency of $50 \%$, bacteria required $29 \mathrm{mM} \mathrm{C} \mathrm{m}^{-2} \mathrm{~d}^{-1}$ or $23 \%$ of the phytoplankton production. Bacterivores grazed an average of $95 \%$ of bacterial production. Although ciliates may also graze bacteria (Sherr \& Sherr 1987), for simplicity we assume that the primary grazer is microflagellates. Assuming a $30 \%$ growth efficiency for the microflagellates (Sherr \& Sherr 1983), the flux to the heterotrophic microflagellate trophic level was $4 \mathrm{mM} \mathrm{C} \mathrm{m} \mathrm{m}^{-2} \mathrm{~d}^{-1}$, only $3 \%$ of the primary production (Fig. 9). With a direct transfer of the microflagellate carbon back to the main food chain, $1.5 \%$ of the primary production was recycled (assuming 50\% respiration upon transfer to the next trophic level). Even less material will be transferred if more steps are required to link with the main food chain.

By examining only bacteria and microflagellates, this exercise suggests that a small percentage of the lost phytoplankton carbon production could be transferred back to the traditional food chain through the microbial loop. These results suggest that the role of the microbial loop may be mineralization of organic matter (Azam et al. 1983). Ducklow et al. (1986) traced an addition of $\mathrm{C}^{14}$ glucose through different size fractions

\section{Carbon $\left(\mathrm{mM} \mathrm{m}^{-2} \mathrm{~d}^{-1}\right)$}

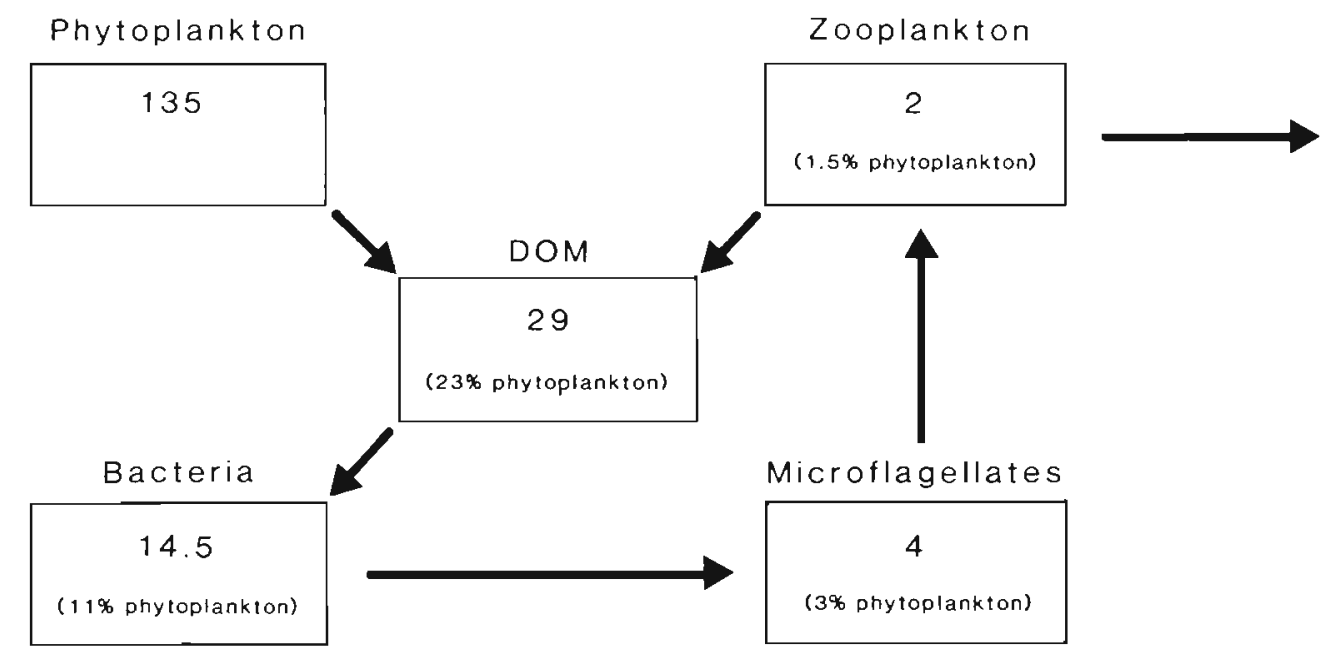

Fig. 9. Box model depiction of Azam et al.'s (1983) microbial loop. Averages of phytoplankton production, bacterial production, and microflagellate grazing of bacteria, between the mouth of the estuary and $75 \mathrm{~km}$ upstream for February to August 1985 . Arrows represent estimates of carbon flow between these trophic levels. Percentages represent the amount of phytoplankton production passing through each trophic level of the microbial loop 
in an enclosed water column in Loch Ewe, Scotland. They reported that only $2 \%$ of labelled substrate was found in larger organisms after the $13 \mathrm{~d}$ incubation experiment, also suggesting that carbon in bacterial production was not transfered to higher trophic levels. Sherr et al. (1987) objected to these conclusions and suggested that the results from one experiment may not be applied to all environments and conditions.

In this simple model, bacterial and microflagellate growth efficiencies are the critical factor in determining the transfer of carbon up the food chain; both values are assumed from the literature. We assumed an average bacterial growth efficiency of $50 \%$. The growth efficiency of bacteria may be substantially higher (Palumbo et al. 1983) or lower (Newell 1984), depending on the substrate composition and environmental conditions. Wright \& Coffin (1984a) and Wright et al. (in press) hypothesized that the growth rate of bacteria in seawater is partially a function of the grazing rate on bacteria. With high grazing rates, bacterial production remains high and, as a result, the growth efficiency should be high. In the absence of grazing, the growth rate should approach zero and the growth efficiency decreases in response to substrate limitation (Pirt 1982). Our data from the Delaware Estuary suggest that bacteria in the lower estuary were grazer limited while in the upper estuary they were substrate limited. Under these different growth conditions it is possible that the growth efficiencies were different. Similarly, microflagellate growth efficiencies may vary in response to changing environmental conditions. However, both microflagellate and bacterial growth efficiencies need to be considerably higher for large percentages of carbon to be transferred to higher trophic levels.

Another factor that may influence the cycling of bacterial production to the main food chain is the structure of the heterotrophic nano and microplankton populations, i.e. the number of trophic transfers before material is cycled to the main food chain. Recently, it has been suggested that several trophic transfers may be involved between the microflagellates and the zooplankton that otherwise would graze phytoplankton (Goldman et al. 1985). However, Sherr et al. (1986a) reported that ciliates are an important component of heterotrophic nanoplankton in estuaries and may also graze bacteria, suggesting one less step in the microbial loop. If ciliates were important grazers of bacteria in these samples (Sherr \& Sherr 1987), the transfer would be more direct, but still only $1.5 \%$ of the lost primary production would be redirected.

To gain a better understanding of the role of the microbial loop in aquatic food webs future studies need to concentrate on: (1) bacterial and microflagellate growth efficiencies, including ranges of efficiencies and the factors that influence them; and (2) the struc- ture of the microbial loop, the relative role of microflagellates and ciliates as bacterial grazers, as well as the predators of microflagellates and ciliates.

Acknowledgements. We thank Drs Mary A. Tyler and Robert Biggs for ship time. J. R. Pennock and S. L. Compton provided phytoplankton production measurements for the February to August 1985 samplings. We are grateful to Mike Montegomery and Steve Compton for their excellent technical assistance and Captain J. Gay and the crew of the R/V Cape Henlopen for the ship support. The reviews of and helpful comments on this manuscript by Drs R. T Wright, D. L. Kirchman and J. R. Pennock are much appreciated. This manuscript is based upon part of a dissertation by R. B. Coffin to the University of Delaware. This research was supported by grants to J. H. Sharp from the Delaware River and Bay Authority and from the Office of Sea Grant (NA80AA-D-00106 and NA83AA-D0017) of the U.S. National Oceanic and Atmospheric Administration.

\section{LITERATURE CITED}

Albright, L. J. (1983). Influence of river-ocean plumes upon bacterioplankton production of the Strait of Georgia, British Columbia. Mar. Ecol. Prog. Ser. 12: 107-113

Andersson, A., Larsson, U., Hagström, $\AA$. (1986). Size-selective grazing by a microflagellate on pelagic bacteria. Mar Ecol. Prog. Ser. 33: 51-57

Azam, F., Fenchel, T., Field, J. G., Gray, J. S., Meyer-Reil, L. A., Thingstad, F. (1983). The ecological role of watercolumn microbes in the sea. Mar Ecol. Prog. Ser 10 $257-263$

Azam, F., Fuhrman, J. A. (1984). Measurement of bacterioplankton growth in the sea and its regulation by environmental conditions. In: Hobbie, J., Williams, P. J. leB. (ed. Heterotrophic activity in the sea. Plenum Press. New York p. $179-196$

Bell, R. T., Ahlgren, G. M., Ahlgren, I. (1983). Estimating bacterioplankton production by measuring $\left[{ }^{3} \mathrm{H}\right]$ thymidine incorporation in a eutrophic Swedish Lake. Appl. environ Microbiol. 45: 1709-1721

Biggs, R. R., Sharp, J. H., Church, T M., Tramontano, M. J (1983). Optical properties, suspended sediments, and chemistry associated with the turbidity maxima of the Delaware Estuary. Can. J. Fish. Aquat. Sci. 40: 172-179

Bratbak, G. (1985). Bacterial biovolume and biomass estimations. Appl. environ. Microbiol. 48: 755-757

Caron, D. A. (1983). Technique for enumeration of heterotrophic and phototrophic nanoplankton, using epifluorescence microscopy, and comparison with other products. Appl. environ. Microbiol. 46: 491-498

Christian, R. R., Hanson, R. B., Newell, S. Y (1982). Comparison of methods for measurement of bacterial growth rates in mixed batch cultures. Appl. environ. Microbiol. 43: $1160-1165$

Church, T M. (1986). Biogeochemical factors influencing the residence time of microconstituents in a large tidal estuary, Delaware Bay. Mar. Chem. 18: 393-406

Cuhel, R. L., Jannasch, H. W., Taylor, C. D. (1983). Microbial growth and macromolecular synthesis in the northwestern Atlantic Ocean. Limnol. Oceanogr. 28: 1-18

Coffin, R. B. (1986). Bacterial dynamics in response to phytoplankton, heterotrophic microflagellates and amino acid pools in the Delaware Estuary. Ph. D. dissertation, University of Delaware, Lewes 
Davis, P. G., Sieburth, J. McN. (1984). Estuarine and oceanic microflagellate predation of actively growing bacteria: estimation by frequency of dividing-divided bacteria. Mar. Ecol. Prog. Ser. 19: 237-246

Ducklow. H. H. (1982). Chesapeake Bay nutrient and plankton dynamics. 1. Bacterial biomass and production during spring tidal destratification in the York River, Virginia, Estuary. Limnol. Oceanogr 27: 651-659

Ducklow, H. W (1985). Nutrient-dissolved oxygen dynamics: roles of phytoplankton and microheterotrophs under summer condition. Bacterioplankton biomass and production. Final report to EPA, February, 1985

Ducklow, H. W., Kirchman, D. L. (1983). Bacterial dynamics and distribution during a spring bloom in the Hudson River plume, USA. J. Plankton Res. 5: 333-355

Ducklow, H. W., Hill, S. M. (1985). The growth of heterotrophic bacteria in the surface waters of warm core rings. Limnol. Oceanogr. 30: 239-259

Ducklow, H. W., Purdie, D. A., Williams, P. J. LeB., Davies, J. M. (1986). Bacterioplankton: a sink for carbon in a coastal marine plankton community. Science 232: 865-867

Eppley, R. W., Sharp, J. H. (1975). Photosynthetic measurements in the central North Pacific: the dark loss of carbon in 24-h incubations. Limnol. Oceanogr. 6: 981-987

Fenchel, $T$ (1982a). Ecology of heterotrophic microflagellates. I. Some important forms and their functional morphology. Mar Ecol. Prog. Ser. 8: 211-223

Fenchel, T. (1982b). Ecology of heterotrophic microflagellates. II. Bioenergetics and growth. Mar. Ecol. Prog. Ser. 8: 225-231

Fenchel, T (1982c). Ecology of heterotrophic microflagellates. III. Adaptations to heterogeneous environments. Mar. Ecol. Prog. Ser. 9: 25-33

Fenchel, $T$ (1982d). Ecology of heterotrophic microflagellates. IV Quantitative occurrence and importance as bacterial consumers. Mar Ecol. Prog. Ser 9: 35-42

Fenchel, T. (1986). The ecology of heterotrophic microflagellates. Adv, microb. Ecol. 9: 57-97

Fuhrman, J. A., Azam, F. (1980). Bacterioplankton secondary production estimates for coastal waters of British Columbia, Antarctica, and California. Appl. environ. Microbiol. 39: 1085-1095

Fuhrman, J. A., McManus, G. B. (1984). Do bacteria-sized marine eukaryotes consume significant bacterial production. Science 224: 1257-1260

Goldman, J. C., Caron, D. A., Andersen, O. K., Dennett, M. R. (1985). Nutrient cycling in a microflagellate food chain. I. Nitrogen dynamics. Mar. Ecol. Prog. Ser. 24: 231-242

Hagström, \&., Larrson, U., Horstedt, P., Normark, S. (1979). Frequency of dividing cells, a new approach to the determination of bacterial growth rates in aquatic environments. Appl environ. Microbiol. 37: 805-812

Hobbie, J. E., Daley, R. J., Jasper, S. (1977). Use of Nuclepore filters for counting bacteria by fluorescence microscopy. Appl environ. Microbiol. 33: 1225-1228

Karl, D. M. (1979). Measurement of microbial activity and growth in the ocean by rates of stable ribonucleic acid synthesis. Appl. environ. Microbiol. 38: 850-860

Kirchman, D., Ducklow, H., Mitchell, R. (1982). Estimates of bacterial growth from changes in uptake rates and biomass. Appl. environ. Microbiol. 44: 1296-1307

Lancelot, C., Billen, G. (1984). Activity of heterotrophic bacteria and its coupling to primary production during the spring phytoplankton bloom in the Southern Bight of the North Sea. Limnol. Oceanogr 29: 721-730

Larsson, U., Hagström, $\AA$. (1982). Fractionated phytoplankton production, exudate release and bacterial production in a Baltic eutrophication gradient. Mar. Biol. 67: 57-70
Lovell, C. R., Konopka, A. (1985). Seasonal bacterial production in a dimictic lake as measured by increases in cell numbers and thymidine incorporation. Appl. environ. Microbiol. 49: 492-500

Malone, T C., Kemp, W M., Ducklow, H. W., Boyton, W. R., Tuttle, J. H., Jonas, R. B. (1986). Lateral variation in the production and fate of phytoplankton in a partially stratified estuary. Mar Ecol. Prog. Ser. 32: 149-160

Newell, R. C. (1984). The biological role of detritus in the marine environment. In: Fasham, M. J. R. (ed.) Flows of energy and materials in marine ecosystems. Theory and practice. Plenum Press, New York, p. 317-343

Newell, R. C., Linely, E. A. S. (1984). Significance of microheterotrophs in the decomposition of phytoplankton: estimates of carbon and nitrogen flow based on the biomass of plankton communities. Mar Ecol. Prog. Ser. 16: 105-119

Newell, S. Y., Christian, R. R. (1981). Frequency of dividing cells as an estimator of bacterial productivity. Appl. environ. Microbiol. 42: 23-31

Parsons, T. R., Takahashi, M., Hargrave, B. (1984). Biological oceanographic processes, 3rd edn. Pergamon Press, New York

Palumbo, A. V., Ferguson, R. L. (1978). Distribution of suspended bacteria in the Newport River Estuary, North Carolina. Estuar. coast. Shelf Sci. 7: 521-529

Palumbo, A. V., Ferguson, R. L., Rublee, P. A. (1983). Efficient utilization of dissolved free amino acids by suspended marine bacteria. J. exp. mar Biol. Ecol. 69: 257-266

Pennock, J. R. (1985). Chlorophyll distributions in the Delaware Estuary: regulation by light-limitation. Estuar. coast. Shelf Sci. $21 \quad 711-725$

Pennock, J. R., Sharp, J. H. (1986). Phytoplankton production in the Delaware Estuary: temporal and spatial variability. Mar. Ecol. Prog Ser. 34: 143-155

Pirt, S. J. (1982). Maintenance energy: a general model for energy-limited and energy sufficient growth. Arch. Mikrobiol. 133: 300-302

Pomeroy, L. R., Deibel, D. (1986). Temperature regulation of bacterial activity during the spring bloom in Newfoundland Coastal Waters. Science 233: 359-361

Rublee, P. A., Merkel, S. M., Faust, M. A., Miklas, J. (1984). Distribution and activity of bacteria in the headwaters of the Rhode River Estuary, Maryland, USA. Microb. Ecol. 10: 243-255

Sanders, R. W., Porter, K. G. (1986). Use of metabolic inhibitors to estimate protozooplankton grazing and bacterial production in a monomictic eutrophic lake with an anaerobic hypolimnion. Appl. environ. Microbiol. 52; 101-107

Sharp, J. H. (1984). Inputs into microbial food chains. In: Hobbie, J., Williams, P. J. LeB. (ed.) Heterotrophic activity in the sea. Plenum Press, New York, p. 101-120

Sharp, J. H., Culberson, C. H., Church, T. M. (1982). The chemistry of the Delaware Estuary: general considerations. Limnol. Oceanogr. 27: 1015-1028

Sharp, J. H., Pennock, J. R., Church, T. M., Tramatono, J. M., Cifuentes, L. A. (1984). The estuarine interaction of nutrients, organics and metals: a case study in the Delaware Estuary. In: Kennedy, V S. (ed.) The estuary as a filter. Academy Press, New York, p. 241-258

Sharp, J. H., Cifuentes, L. A., Coffin, R. B., Pennock, J. R., Wong, K.-C. (1986). The influence of river variability on the circulation, chemistry and microbiology of the Delaware Estuary. Estuaries 4A: 261-269

Sherr, B. F., Sherr, E. B. (1983). Enumeration of heterotrophic microprotozoa by epifluorescence microscopy. Estuar. coast. Shelf Sci. 16: 1-7 
Sherr, B. F., Sherr, E. B., Newell, S. Y (1984). Abundance and productivity of hetertrophic nanoplankton in Georgia coastal waters. J. Plankton Res. 6: 195-202

Sherr, E. B., Sherr, B. F., Fallon, R. D., Newell, S. Y. (1986a). Small aloricate ciliates as a major component of the marine heterotrophic nanoplankton. Limnol. Oceanogr 31: $177-183$

Sherr, B. F., Sherr, E. B., Andrew, T L., Fallon, R. D., Newell, S. Y. (1986b). Trophic interactions between heterotrophic protozoa and bacterioplankton in estuarine water analyzed with selective metabolic inhibitors. Mar. Ecol. Prog. Ser. 32: 169-179

Sherr, E. B., Sherr, B. F. (1987). Bacterivory in pelagic ciliated protozoa. Nature, Lond. 325: 710

Sherr, E. B., Sherr, B. F., Albright, L. J. (1987). Bacteria: link or sink? Science 235: 88

Simon, M. (1987). Biomass and production of small and large free-living and attached bacteria in Lake Constance. Limnol. Oceanogr. 32: 591-607

Strickland, J. D. (1960). Measuring the production of marine phytoplankton. Fish. Res. Bd Can. Bull No. 122

Strickland, J. D., Parsons, T. R. (1972). A practical handbook of seawater analysis. Bull. Fish. Res. Bd Can. 167

Taylor, G. T., Pace, M. L. (1987). Validity of eucaryote inhibitors for assessing production and grazing mortality of marine bacterioplankton. Appl. environ. Microbiol. 53: $119-128$

Turley, C. M., Lochte, K. (1985). Direct measurement of bacteria productivity in stratified waters close to a front in the Irish Sea. Mar. Ecol. Prog. Ser. 23: 209-219
Vaatanen, P. (1980). Factor analysis of the impact of the environment on microbial communties in the Tvarminne area, Southern Coast of Finland. Appl. environ. Microbiol. 40: 55-61

Williams, P. J. LeB. (1981). Incorporation of microheterotrophic processes into the classical paradigm of the planktonic food web. Kieler Meeresforsch., Sonderh. 5: 1-28

Wilson, C. A., Stevenson, L. H. (1980). The dynamics of the bacterial population associated with a salt marsh. J. exp. mar. Biol. Ecol. 48: 123-138

Wright, R. T. (in press). Methods for evaluating the interaction of substrate and grazing as factors controlling planktonic bacteria. Arch. Hydrobiol.

Wright, R. T., Coffin, R. B. (1983). Planktonic bacteria in estuaries and coastal waters of northern Massachusetts: spatial and temporal distribution. Mar. Ecol. Prog. Ser. 11: 205-215

Wright, R. T., Coffin, R. B. (1984a). Factors affecting bacterioplankton density and productivity in salt marsh estuaries. In: Klug, M. J, Reddy, C. A. (ed.) Current perspectives in microbial ecology. Proc. 3rd Int. Symp. Microb. Ecol. Michigan State Univ., 7-12 Aug. 1983. Am. Soc. Microbiol.

Wright, R. T., Coffin, R. B. (1984b). Measuring microzooplankton grazing on planktonic marine bacteria by its impact on bacterial production. Microb. Ecol. 10: 137-149

Wright, R. T., Coffin, R. B., Lebo, M. (in press). Dynamics of planktonic bacteria and heterotrophic microflagellates in the Parker Estuary, Northern Massachusetts. Cont. Shelf Sci. 